Karadeniz Uluslararası Bilimsel Dergi

Volume: 50, Summer-2021, p. (358-368)

ISSN: 1308-6200 DOI Number: https://doi.org/10.17498/kdeniz.947536

Research Article

Received: May 3, 2021 | Accepted: June 6, 2021

This article was checked by turnitin.

\title{
IMPACT OF THE TYPE OF MILITARY EDUCATION ON THE PSYCHOLOGICAL CHARACTERISTICS OF OFFICERS' SOCIAL COMPETENCE
}

\section{ВЛИЯНИЕ ВОЕННОГО ОБРАЗОВАНИЯ НА ПСИХОЛОГИЮ И СОЦИАЛЬНЫЕ КОМПЕТЕНЦИЙ ОФИЦЕРОВ}

\section{ASKERİ EĞITIMIMININ SUBAYLARIN SOSYAL YETERLIILIĞİ İLE PSİKOLOJİK ÖZELLİKLERİNE ETKİSI}

\author{
Nanuli (Nana) TSKHVEDADZE* \\ Ketevan LOMSADZE* \\ Beka TOLIASHVILI***
}

\begin{abstract}
Modern changing world has raised the issue about new interpretation of professionalism and professionals for science. Consequently, new concepts - competence and adequacy has appeared.

In the context of the country's independence, the military education system has changed: military education or military training takes place according to two modules: the old (defense-oriented) and the "new" (cooperation-oriented). Accordingly, the competencies of the officers trained under these two systems should also be different according to these two accents. The aim of the study was therefore to study, describe and analyze the effects of the possible impact of the education system on the formation of psychological characteristics defining the social competence of officers trained in different military education systems, as well as the size and limits of influence.

Based on hypothesis of research, the object of the research is: Self-esteem, tolerance, subjective assessment of happiness and motivation to achievement.

Interviewer and testing methods were used in the study. The research tool was an integrated test questionnaire, which included: A scale to measure the feeling of happiness. The scale is formulated in the form of a single question. It is obtained by reconstructing a Fordis happiness measurement instrument. As a result of adapting to the Georgian population, the question is

\footnotetext{
" ORCID: 0000-0002-1921-8136 Assoc. Prof Dr. Nanuli Tskhvedadze, Sokhumi State University, Tbilisi, Georgia; cxvedadzenana@ gmail.com

** ORCID: 0000-0002-9684-5141 Assoc. Prof Dr. Ketevan Lomsadze, Gori State Teaching University, Gori, Georgia; ketilomsadze@ gmail.com

*** ORCID: 0000-0003-3509-6033 Assoc. Prof. Dr. beka Toliashvili, Gori State Teaching University, Gori, Georgia; beka.tol@list.ru
} 


\section{Impact Of The Type Of Military Education On The Psychological Characteristics ...}

as follows: "In general, can you say that you are .... very happy; Quite happy; Not so happy; More unhappy; Bogdarus Scale for Tolerance for Different Groups, and Achievement Motivation Test Questionnaire (22 questions) (Dubenik N., 2009);

Data were processed using SPSS, differences in validity were checked by t-test.

The hypothesis of the research that the structure of the psychological characteristics of social competence of the officer's trained in the military education system based on partnership for the protection of global security and democracy should have been different from the structure of the psychological characteristics of social competence of the officer's trained in the military education system, is confirmed by the research results.

Keywords: competence, social competence, tolerance, sense of happiness, achievement, adaptability.

\section{АННОТАЦИЯ}

Современный быстроразвиваюший и переменчивый мир перед учеными ставит вопрос новой интерпретаций профессиональной квалификаций и профессионализма. При независимости страны, военная образовательная система потерпела изменения, которая осуществлялась по двум модулям: так называемом „старого,” ( ориентированное на оборону) и „нового,, (ориентированное на сотрудничество). Соответственно, компетенций офицеров, подготовленных в рамках этих двух систем, должны быть разными. Исходя из этого целью нашего исследования мы выбрали предполагаемые эффекты влияния образовательной системы на формирование некоторых психологических характеристик офицеров, подготовленных в разных военных образовательных системах. Также изучение, описание и анализ размеров и границ этого влияния.

Согласно гипотезы объектом исследования является: самооценка, толерантность, субъективная оценка счастья и мотивация достижения.

В исследовании использовались методы интервью и тестирования. В процессе исследования применялись интегрированный опросный лист, в котором находилась шкала для измерения ощущения счастья . Эта шкала было сформулировано в форме одного простого предложения.Он получен путем реконструкции инструмента для измерения счастья Фордиса. В результате адаптации к грузинскому населению , вопрос-предложение выглядит так-«В целом, можете ли вы сказать, что вы ... очень счастливы; Довольно счастливы; Не очень счастливы; Еще несчастнее». Также использовали шкалу толерантности Богдаруса, для разных групп и опросник для теста мотивации достижений (22 вопросов) (Dubenik N., 2009);

Результаты исследования были разработаны с помощью SPSS, а достоверности различии было проверено с помощью $\mathrm{t}$ теста.

Гипотеза исследования, что структура психологических характеристик офицеров, подготовленных в системе военного образования, основанную на партнерство, глобальную безопасность и демократию, различается от структуры офицеров подготовленных в системе военного образования, основанную на собственной безопасности, доказано результатами исследования.

Ключевые слова: компетенция, социальная компетенция, толерантность, ощущение счастья, достижение, адаптивность.

\section{ÖZ}

Hızla gelişen ve değişen modern dünya, bilim adamlarının profesyonel yeterliliklerini yeniden gözden geçirmek sorunlarıyla karşı karşıya getirmektedir. Ülkenin bağımsızlığı ile birlikte, askeri eğitim sistemi, iki parça halinde gerçekleştirilen değişikliklere uğradı: 


\section{Nanuli (Nana) TSKHVEDADZE - Ketevan LOMSADZE - Beka TOLIASHVILI}

Birincisi "eski" (savunmaya odaklı) ve ikincisi "yeni" (iş birliğe odaklı). Buna göre, bu iki sistem içinde yetişen subayların yetkinlikleri farklı olmalıdır. Çalışmamızın amacından hareketle farklı askeri eğitim sistemlerinde yetişmiş subayların bazı psikolojik özelliklerinin oluşumunda eğitim sisteminin etkilerini irdeledik. Ayrıca bu etkinin boyutu ve sınırlarının incelenmesi, tanımlanması ve analizi de yapılmıştır.

Hipoteze göre çalışmanın amacı kendini sorgulama, hoşgörü, mutluluğun öznel değerlendirmesi ve başarı motivasyonu olmuştur.

Çalışmada mülakat ve test yöntemleri kullanıldı. Çalışma sırasında mutluluk hissini ölçmek için bir ölçek olarak kullanıla karma anket kullanıldı. Bu ölçek, basit bir cümle şeklinde formüle edilmiştir. Fordis'in mutluluk ölçme aracı yeniden yapılandırılarak elde edildi. Gürcü nüfusuna verilen bir adaptasyonun sonucu olarak, soru önerisi şu oldu: "Çok mutlu musunuz? Yeterinceye kadar mutlu musunuz? O kadar da mutlu değilsiniz? Daha fazla mutsuz musunuz?" Ayrıca farklı gruplar için Bogdarus tolerans ölçeğini ve başarı motivasyon anketini kullandık (toplam 22 soru) (Dubenik N., 2009).

Çalışma sonuçları SPSS kullanılarak geliştirilmiş ve farkın önemi bir " $t$ ” testi kullanılarak doğrulanmıştır.

Ortaklığa, küresel güvenliğe ve demokrasiye dayalı askeri eğitim sisteminde yetişen subayların psikolojik özellikleri, savunma askeri eğitim sisteminde yetişmiş subay yapısından farklı olduğunu göstermiş ve araştırmanın hipotezini doğrulamıştır.

Anahtar kelimeler: yeterlilik, sosyal yeterlilik, hoşgörü, mutluluk duygusu, başarı, uyum sağlama.

\section{Introduction}

Modern changing world has raised the issue about new interpretation of professionalism and professionals for science. Consequently, new concepts competence and adequacy has appeared.

D. Raven is an establisher of the concept of adequacy, who noted successful activities of human beings, but the notion "competence" was introduced in 1959 by White, in order to describe the peculiarities of individuality that are closely linked to the successful performance of work and high motivation. He described interconnection between cognitive competences and motivational tendencies and determined the competence as "Effective human relationship with the environment". White asserted that "adequate motivation" exists along with the competence, which should be considered as achieved ability (Chavchavadze, Chigogidze 2009).

The notion of competence is not precisely and unambiguously defined. There are different interpretations of this notion.

American scientists characterize competence as the skills beyond cognitive abilities, such as: social skills, self-regulation and self-consciousness. Competences for them are mostly behavioral characteristics and consider that, unlike individuality and intellect, this competence can be created through learning and development. Competencies are defined as the main characteristics of humanity which reasonably are associated with the successful completion of the work. According to Makleland, the competence includes: 1. Motives; 2. Features; 3. Values; 4. Content of the knowledge; 5. Cognitive and behavioral skills - Any individual peculiarities which can be measured or counted. It is considered that according to these peculiarities, it is possible to differentiate people. (Raven D., 2002; Хекхаузен,1986). 
Since 1996, the German education system granted the priority to the competence of action. Standard typology of competences is compiled for every year of vocational learning. It includes: 1. Competences related to the field of activity 2. General cognitive competences. 3. Personal competences. 4. Social competences. (D. Charkviani 2001)

Competences related to the field of activity describe the human readiness and ability to perform tasks based on the subjective knowledge skills and consistently assess the results in accordance with the goals.

General cognitive competences mean human ability to think and act through the method that will help to solve the problem. Thus, subjective competence includes both functional and cognitive aspects.

\section{Research Methods}

Interviewer and testing methods were used in the study. The research tool was an integrated test questionnaire, which included:

A scale to measure the feeling of happiness. The scale is formulated in the form of a single question. It is obtained by reconstructing a Fordis happiness measurement instrument. As a result of adapting to the Georgian population, the question is as follows: "In general, can you say that you are .... very happy; Quite happy; Not so happy; More unhappy (Pachkoria M., 2014).

Bogdarus Scale for Tolerance for Different Groups Adapted to the Georgian Population (Sumbadze N., et al., 2007) and Achievement Motivation Test Questionnaire (22 questions) (Dubenik N., 2009);

Multidimensional self-report scales are used to measure self-esteem. The methodology is developed by $\mathrm{d}$. Uznadze Institute of Psychology (author M. Baliashvili); Results from 10 blocks, each containing 5 bipolar oils. Each of these blocks implies certain dimensions characteristic of a person. These blocks are: 1 . Social reputation; 2. Wisdom; 3. General impression that a person makes on others; 4. temperament; 5. Willingness; 6. Morality; 7. Physical status and health; 8.Politeness; 9. Feelings; 10. Physical beauty (appearance) (Baliashvili M., 1998).

Data were processed using SPSS, differences in validity were checked by ttest.

\section{Discussion}

Personal competences describe human readiness and ability to understand, analyze and evaluate possible ways, requirements and limitations of the development; In personal, work and social life, develop own skills, choose and implement life plans. This competence includes personal characteristics such as independence, critical reasoning skill, self-confidence, reliability, responsibility and a sense of commitment in connection with professional and moral values. (Jonathan Winterton, 2005; Raven D., 2002; Мачехина О. Н., Шолохова М.А.,2005)

Thus, personal competence involves cognitive and social competences.

Social competences describe human readiness, ability to establish and strengthen relationships, determine and see as some benefit as well as danger in 


\section{Nanuli (Nana) TSKHVEDADZE - Ketevan LOMSADZE - Beka TOLIASHVILI}

relationship, to cooperate with others with rational and rules that strengthen the sense of solidarity and social responsibility.

In Austria, there are cognitive, social and personal competences, cognitive competencies are the knowledge, skills and abilities, which can be used in concrete and other mixed type activities. It is considered that security protection of the workplace and the proper management is directly related to theoretical thinking and professionalism.

The issue of adequacy and competence is also relevant in Russia [3].They allocate different competences: the competence of learning, communicative competence, informational competence and social competence. It is considered that these competences play an important role in forming a person. Social competence is defined as a complex of individual character, knowledge, skills and sociopsychological characteristics that define the level of relationship between individuals and socius, enables them to make the right decision in different life situations. Social competence is considered closely linked to social roles, but it is more than the role, because it implies an individually, outstanding approach to the role and disclosure. The roles are not only played, but also written. They can also be copied; therefore an important part of the social competence is added to the experience of a person. Psychological criteria such as tolerance, adaptability, self-confidence, oriented to success, non-conflictness is considered as part of social competence. (Мачехина O. Н., Шолохова М.А.,2005).

Therefore, the notion " adequacy" as a combination of certain competences contains complex and multidimensional content that combines working-practical social, philosophical and other characteristics of the person; The vast majority of characteristics are acquired; is achieved by learning; is the effects of experience, which ultimately lead to the performance effectiveness of the work. Due to the fact that the military service is one of the type of work, the efficiency of its fulfillment, along with professional knowledge, implies certain social competences of the officer. In other words, combination of the skills and personal characteristics that he has acquired and strengthened in the process of military education.

Under the independence of the country the military education system has changed.

Military education or military training was produced according two so called modules „Old" (defense oriented) and "New" (collaboration oriented). Consequently, the competences of the officers prepared within these two systems should be different in accordance with these two accents. Particularly, in the part of the social competence of officers, the essential characteristic of which is the personal characteristics of the officer (Cxvedadze, Toliashvili 2018 ). Therefore, the aim of the research is to study, describe, and analyze the possible effects of impact of the education system on the formation of personal dispositions that determine the social competence of officers trained in different military education systems, as well as the size and bounds of impact.

Especially in the part of officers' social competence, the essential characteristic of which is the personal characteristics of the officer. The aim of the 
study was therefore to study, describe and analyze the effects of the possible impact of the education system on the formation of psychological characteristics defining the social competence of officers trained in different military education systems, as well as the size and limits of influence.

Due to the aim, the objectives of the research are :

$>\quad$ Identification and determination of personal characteristics and essential features of acting officers trained in different military education system;

$>$ Identification and evaluation of the motivational-behavioral structure of acting officers trained in different military education system;

Comparative analysis of the personal characteristics and motivational-behavioral structure of acting officers trained in different military education system and identification and determination of personal characteristics.

With respect to behavior, the predictive value of the personal characteristics, leads the actuality of the research in two directions: The first is related to the possibility of predictability of organizational behavior of officers trained by each system and the second is related to the evaluation of the efficacy of the military training-teaching process itself. Which, along with the theoretical, has practical importance for the management of the military education system in the reform process.

Since traditional and modern military education systems have different basic principles (competition and cooperation), which create different motivations for the behavior of the officer and need different skills, it is likely that the officers trained within these systems should differ from each other with their personal and behavioral motivation structure. From this admission, the hypothesis of the research follows: If the officer has a military education based on partnership for protection of global security and democracy, then his personal and motivational structure of behavior will be different from the personal and motivational structure of the officer who is trained in the military education system based on his own safety. In particular, in the first case, personal motivational structure will be oriented on cooperation, in the second case - oriented on competition.

Based on hypothesis of research, the object of the research is: Self-esteem, tolerance, subjective assessment of happiness and motivation to achievement.

The subject of the research: the impact of the education system based on partnership and competition, on the self-assessment of the officers, tolerance, the feeling of happiness and motivation to achievement.

Study groups - Two groups of acting officers trained in different systems of education: a group of 30 officers who are trained within traditional (old) systems and a group of 30 officers trained within new education systems.

Control Group - A group of 30 civil persons with higher education.

The originality of the work (value): In Georgian reality, the novelty of empirical researches aimed to comparatively analyzing and evaluating the effect of impact of old and new military education on personal and behavioral motivation structure (on social competence) of the officers. 


\section{Nanuli (Nana) TSKHVEDADZE - Ketevan LOMSADZE - Beka TOLIASHVILI}

Testing was done individually with each test subject. Respondents' participation in the study was voluntary.

Data were processed using SPSS, differences in validity were checked by ttest.

\section{Description of results}

The data obtained as a result of data processing are presented in the form of tables and diagrams.

The achievement test results are presented in Table \# 1. Based on the normative indicators of the test, all three groups are characterized by an average level of achievement. But in this range, as can be seen from the table, the so-called. The average achievement rate of a group of senior officers is relatively low. The difference is statistically reliable, as the so-called. From the average rate of new officers $(\mathrm{M}$ (old officers) $=12.6 ; \mathrm{M}$ (new officers $)=13.6 \mathrm{t}(58)=2,021 \mathrm{p}<0.5)$, as well as civilians

\section{C.P. N M min max Std}

Table \# 1 . Achievement test results in the study and control group. $\mathrm{p}<0.2$ ).

From the mean $(\mathrm{M}$ (senior officers $)=12.6 \mathrm{M}($ civilians $)=13.6 \mathrm{t}(58)=2,391$

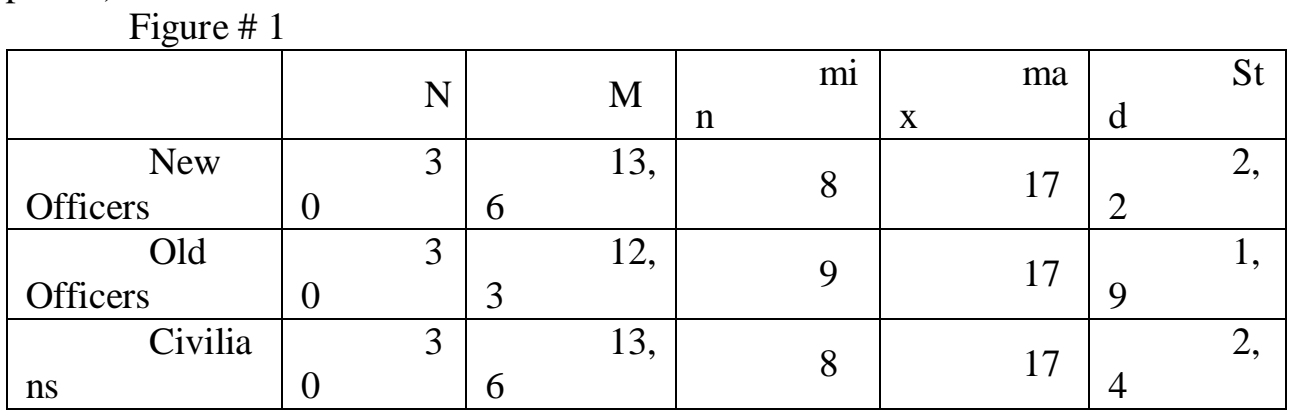

The data on the Happiness Survey and Tolerance Survey for Different Social Groups are presented in Figure \# 1.

1. The figures are statistically significantly different from the data of both groups $(\mathrm{M}$ (new officers $)=1.6 ; \mathrm{M}$ (civilians) $=2.1 \mathrm{t}(58)=2,124 \mathrm{p}<0.5)$. $\mathrm{M}$ (old officers) $=2.1 \mathrm{t}(58)=2,009 \mathrm{p}<0.5)$. 


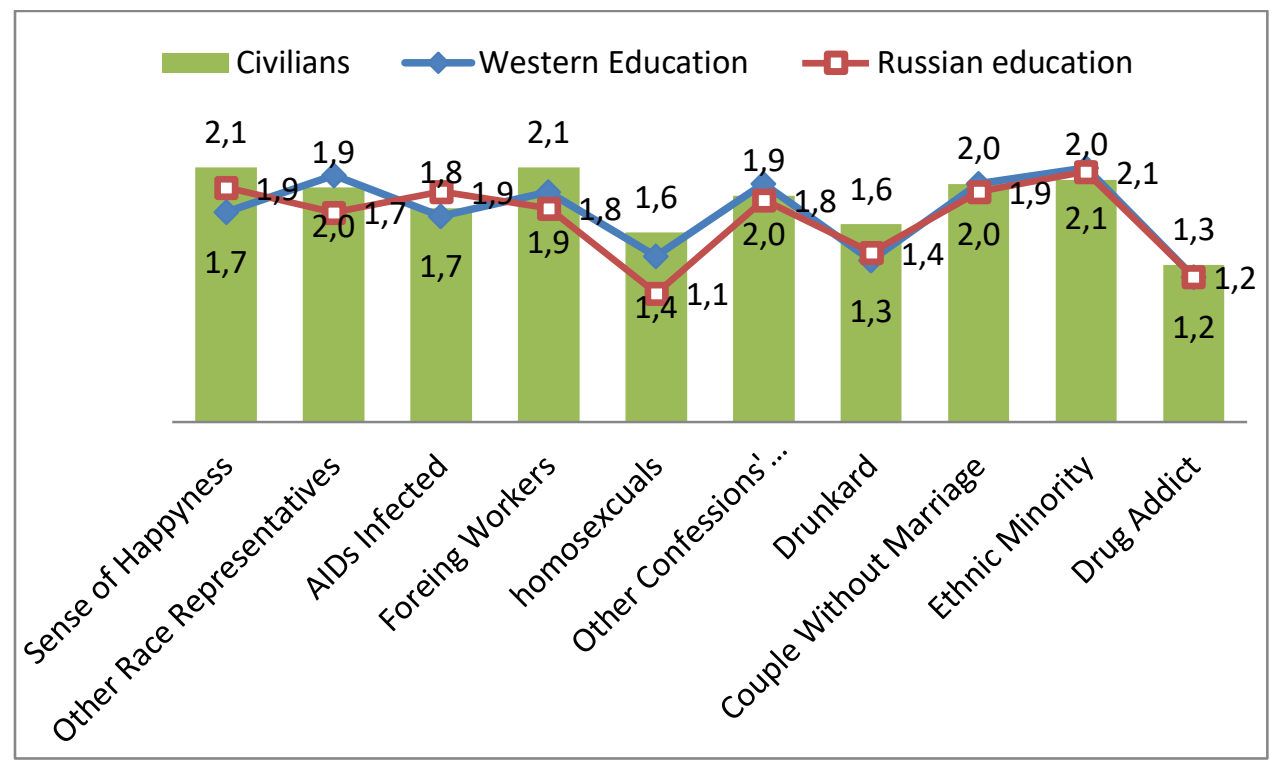

\section{Sense of happiness and tolerance}

According to the sense of happiness, civil persons feel the most happy. The most "unhappy" - a group of officers trained in the modern education system. In relation to members of other races, the most tolerant is the group of new officers (M $=2,1)$. The difference is plausible with respect to the group of senior officers (M senior officers $=1.7, \mathrm{t}(58)=2,009 \mathrm{p}<0.5)$ but not with respect to civilians. $\mathrm{M}$ $($ civilians $)=1.8 \mathrm{t}(58)=1,642 \mathrm{p}>0.5)$.

As for tolerance, the most tolerant is the group of civil persons, the least tolerant - military officers with old education.

Differentiated discussion of the attitudes towards individual groups used to assess general tolerance show that:

$>\quad$ In relation to members of other races, the most tolerant is the group of new officers $(M=2,1)$. The difference is plausible with respect to the group of senior officers ( $\mathrm{M}$ senior officers $=1.7, \mathrm{t}(58)=2,009 \mathrm{p}<0.5)$ but not with respect to civilians. $\mathrm{M}$ (civilians) $=1.8 \mathrm{t}(58)=1,642 \mathrm{p}>0.5)$.

$>\quad$ For other race representatives, the most tolerant are the group of new officers, the most intolerant -group of old officers;

Older officers are the most tolerant of AIDS infected; foreign workers;

Unlike civilians, military personnel are equally intolerant towards

Homosexuals are the most unacceptable for old officers, and the most acceptable for civilians; $((\mathrm{M}$ (old officers) $=1,1 ; \mathrm{M}$ (new officers) $=1,6 \mathrm{t}(58)=$ $2,009 \mathrm{p}<0,5) ; \mathrm{M}$ (senior officers $)=1.1, \mathrm{M}$ (civilians) $=1.9 \mathrm{t}(58)=3,261 \mathrm{p}<0.02)$;

$>\quad$ There is no difference between groups of people of other faiths. The Uwela group is equally tolerant of other religious people; 


\section{Nanuli (Nana) TSKHVEDADZE - Ketevan LOMSADZE - Beka TOLIASHVILI}

New officers are the most tolerant for persons with other confessions and the most intolerant are the older officers; Unlike the civilians, Intolerable of new officers $(\mathrm{M}$ new officers $=1.1, \mathrm{M}$ (old officers) $=1.4 \mathrm{t}(58)=1,642 \mathrm{p}>0.5 ; \mathrm{M}$ (new officers $)=1.1, \mathrm{M}($ civilians $)=1.6 \mathrm{t}(58)=2.009 \mathrm{p}<0.05)$;

All three groups are equally tolerant towards the couples without marriage;

$>\quad$ All three groups are tolerant towards ethnic minorities. However, old officers are the most tolerant towards them;

$>\quad$ All three groups are intolerant towards drug addicts; however, military personnel are more intolerant than civilians.

1. Summary: Comparison of old and new officers shows that the new officers are more tolerant of different races and homosexuals and intolerant of drinkers. Older officers - show more tolerance towards people living with AIDS and smokers and extreme intolerance towards homosexuals.

\section{Research data of self-esteem}

General self-esteem indicators of all three groups are presented in Diagram

It should be noted that all three groups have high self-esteem. Among them a new group of officers have exceptionally high self-esteem and the old officers have the lowest self -esteem.

New officers have moderate self-esteem only in the estimation of the appearance. $(\mathrm{M}=37,7)$ According to all other parameters, their self-esteem is high to moderate. Especially in such components of self-esteem, as physical status and health $(M=46,6)$, intelligence $(M=45,7)$, politeness $(M=45)$ and willpower $(\mathrm{M}=44,8)$.

All features of self-estimation of old officers are in moderate boundaries, except for the self-esteem in the components of morality $(\mathrm{M}=43,8)$, politeness $(M=40)$, consciousness and feelings $(M=39,7)$.

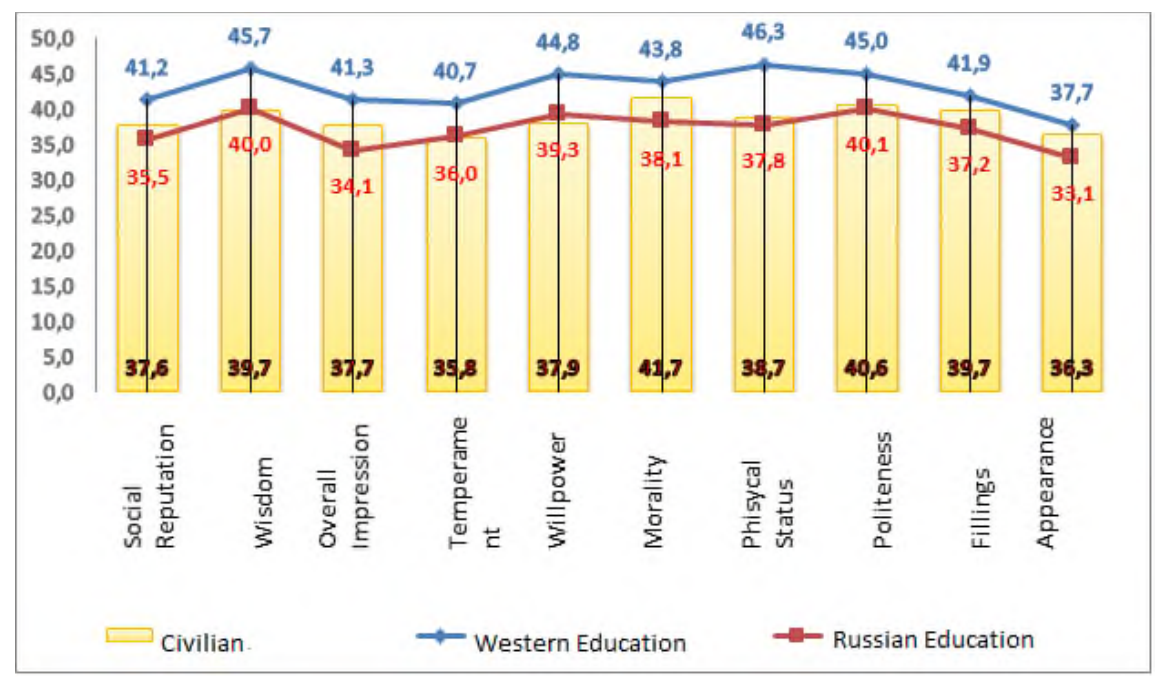


Diagram \# 2. Differentiated comparison of study and control group selfassessment dimensions.

According to the statistical analysis of the data, the officers trained in the new and old military education system differ in the following components of selfassessment: Officers with social reputation - Western military education give themselves a higher rating on this mark ( $\mathrm{M}$ new officers $=41.1, \mathrm{M}$ (old officers) = $35,5 \mathrm{t}(58)=2,660 \mathrm{p}<0.01)$; Wisdom - new officers consider themselves more competent than old ones $(\mathrm{M}$ new officers $=45.7, \mathrm{M}$ (old officers) $=40 \mathrm{t}(58)=3,486$ $\mathrm{p}<0.02$ ); Unlike the old officers, they think they make a particularly good impression on people $(\mathrm{M}$ new officers $=41.1, \mathrm{M}$ (old officers) $=34.1 \mathrm{t}(58)=3,541 \mathrm{p}<0.001)$; Compared to the corps of old officers, the new generation of officers consider themselves more purposeful (voluntary) (M new officers $=44.8, \mathrm{M}$ (old officers) = $39.3 \mathrm{t}(58)=2,012 \mathrm{p}<0.5)$, with high morals $(\mathrm{M}$ new Officers $=43.8 \mathrm{M}$ (Old Officers $)=38.1 \mathrm{t}(58)=2,301 \mathrm{p}<0.5)$ and are considered physically strong, healthy people $(\mathrm{M}$ New Officers $=46.3, \mathrm{M}$ (Old Officers $)=37,8 \mathrm{t}(58)=3,654 \mathrm{p}<0.001)$. As for the components of temperament, politeness, feelings and outward charm. The higher self-esteem of young officers in these areas did not appear to be statistically reliable compared to the self-assessment rates of older officers. This means that the groups of officers do not differ from each other according to these components.

\section{Conclusion}

The generalized results of the data are as follows:

1. Officers trained in a different military education system do not differ in achievement motivation and, like civilians, are characterized by an average level of achievement;

2. Young officers feel less happy than "old" officers;

3. Young officers show more tolerance and intolerance towards lots towards different races and social groups of homosexuals than the old ones. Older officers are even more tolerant of those infected with shingles;

4. The new generation of officers is distinguished by high self-esteem. The so-called "The self-esteem of old officers is in the moderate range;

5. The distinctive structure of the old and new generations of officers is the markedly high self-esteem of the new officers in the components of social reputation, intelligence, positive social attraction, willpower, morality and physical strength and health.

The hypothesis of the research that the structure of the psychological characteristics of social competence of the officer's trained in the military education system based on partnership for the protection of global security and democracy should have been different from the structure of the psychological characteristics of social competence of the officer's trained in the military education system, is confirmed by the research results. But what is the size and what is the share of 


\section{Nanuli (Nana) TSKHVEDADZE - Ketevan LOMSADZE - Beka TOLIASHVILI}

education system in this difference and should be solved afterwards by the more large-scale research.

Future research should address the conflicting results obtained in the case of new officers - high self-esteem amid low feelings of happiness. What this incompatible combination is due to or what it is related to also requires further research.

\section{Bibliography}

Baliashvili M. Social mood formation and person's activity, Tb. 1980.

Chavchavadze N., Chigogidze K., About the psychological essence of competence, Journal - Psychology Herald.\#1, Tbilisi 2008. p. 189-192.

Charkviani D.Psychology in industrial organizations, Tbilisi 2001.

Japaridze's M. editing, Educational Psychology, Assistant Manual for Pedagogical University Students, Tb. 2005.

Pachkoria M. Adaptation of the test of happiness research.Master's thesis Sokhumi University 2014.

Tskhvedadze N., Toliashvili B., Personal dispositions defining the social competence of officers trained in different systems of military education, Gori University Magazine .... 2018.

Raven, Competency in the Modern Society, Announcement, Development Realization. Moscow Cognito-Centre. 2002.

Delamar Francois, Le Deist, Jonathan Winterton: „Competentcy”, 2005. France Business School of Toulouse.

9.Мачехина О. Н., Шолохова М.А., Социальная комретенция старшекласниковю Москва. 2005.

Аронсон Э, Уилсон Т, Эйкерт Р. Социальная Психологиа, Маск,2002.

Дубениюк Н. Болъшая энциклоредия психологических тестов, изд.,Эксмо,Масква 2009.

Маклакова А. Г. Военная психология: Учебник для вузов. - СПб.: Питер, 2005.

Военная психология методология, теория, практика -Учебно-методическое пособие -Военный университет, Кафедра психологии, Москва 1996 год.

Занюк С., Психология мотивации. Теория и практика мотивирования. Мотивационный тренинг. Научное издание Серия „новейшая психологця,, (выпуск 7) опубликован на саит PPESSI (HTRSON).

Запесоцкий А. С. Гуманитарная культура и гуманитарное образование // Magister. - 1997. - № 1.

Парыгин Б. Д., Социальная психология. Проблемы методологии, истории и теории. - СПб.: ИГУП, Санкт-Петербург, 1999.

Хекхаузен -Мотивация и деятельность ,Т. 1; Т. 2 М. 1986. 